\title{
Capital Flows and Policy Reforms in Turkey After the Crises
}

\author{
Nuray Terzi \\ Marmara University \\ Department of Economics
}

\section{Doi:10.5901/ajis.2013.v2n8p595}

\begin{abstract}
Capital flows are a key aspect of the global monetary system and have increased significantly in recent years. Capital flows can have substantial benefits for countries, including by enhancing efficiency, promoting financial sector competitiveness, and facilitating greater productive investment and consumption smoothing. Capital flows can also carry some risks; their size and volatility can also cause policy challenges and they can reduce discipline in financial markets and public finances, tighten financing constraints by restricting the availability of foreign capital. The global financial crisis has caused the swings of capital flows in financial markets and lead to policy reforms in developing countries. The aim of the study is to analyze the capital flows and policy reforms in Turkey after global financial crises.
\end{abstract}

\section{Introduction}

The 1970s witnessed a remarkable boom of capital flows to emerging economies. The dramatic surge in international capital flows was triggered by the oil shock in 1973-1974, the growth of the Eurodollar market and the remarkable increase in bank lending during 1979-1981 (Kaminsky, 2005, p.2).

Capital flows are a key aspect of the global financial system. They can have substantial benefits for countries, including by enhancing efficiency, promoting financial sector competitiveness, and facilitating greater productive investment and consumption.

If capital flows don't properly managed, they can cause economies to overheat, increase exchange rate volatility, and lead eventually to large outflows (Lopez-Mejia, 1999). Large capital inflow may also lead to excessive money supply changes and consequent pressures on prices, the exchange rate, and deterioration in the current account balance. There may be other associated dangers of foreign investment: currency appreciation, reduced scope for independent macroeconomic policy action, greater exposure to external shocks, demands for protection in local markets, some loss of control of foreign owned domestic industry, disruption of national capital markets, asset inflation, increased volatility in financial and exchange markets etc. (World Bank, 1995).

The global crisis that started in mid-2007 brought an abrupt stop to the sustained rise in international financial integration over the previous decade. Global capital flows had steadily increased from less than 7 percent of world GDP in 1998 to over 20 percent in 2007 (Milesi-Ferretti and Tille, 2010, p.2).

The global financial crisis has also caused the swings of capital flows in financial markets and lead to policy reforms in developing countries. In this context, the study is aim to analyze the capital flows and policy reforms in Turkey after global financial crises. In order to achieve this aim, this paper is organized as follows. Section 2 examines capital flows to developing countries. Section 3 describes the global financial crsisis and Turkey. Section 4 outlines capital flows and policy reforms. Last section provides a conclusion.

\section{Capital Flows to Developing World}

The developing world has become more closely integrated with the global financial system especially over the past two decades. This integration is due to both pull and push factors; 'pull' factors include continuous liberalisation of capital accounts and domestic stock markets as well as large scale privatisation programmes, while 'push' factors include the increasing importance of institutional and the spread of depositary receipts, and cross-listings (Cali et al, 2008, p.2).

Increased financial integration of developing countries increased economic growth rates, but also increased the speed and the number of channels through which financial crises in general, and the current financial turmoil in the specific case, propagated across the developing world. Indeed, crossborder capital flows between developed and developing countries are sensitive to macroeconomic and financial conditions not only in developing economies but also 
in mature markets, and the transmission of shocks through these financial channels is much quicker than through real channels. For example, a shock in income growth in a developed country have a gradual impact on a developing country through trade channels, but could have a much quicker effect on economic activity of that country through correlations in stock market fluctuations (Cali et al, 2008, p.2).

An important feature of capital flows is quitely to be volatile. The figure 1 shows the private financial flows to emerging and developing economies. As the figure shown, there have been swings in capital flows between in 2005 and in 2012 in emerging and developing economies.

Figure 1. Emerging Market and Developing Economies: Private Financial Flows 2005 -2014 (Billions of US dollars)

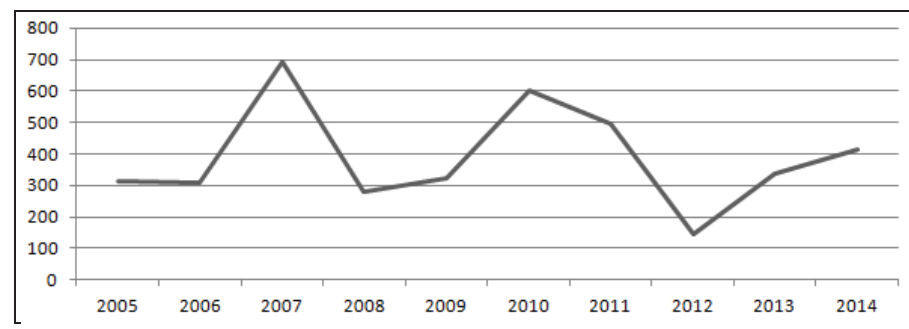

Source: IMF, World Economic Outlook, April 2013.

Capital flows can go to developing countries in a different way: foreign direct investment, portfolio investment and other investment like credits. The figure 2 shows the composition of the private financial flows in developing and emerging economies. Foreign direct investment is the larger component of capital flows between in 2005 and in 2012. By contrast, portfolio investment and other investment are going less than the foreign direct investment.

Figure 2. The Composition of the Private Financial Flows

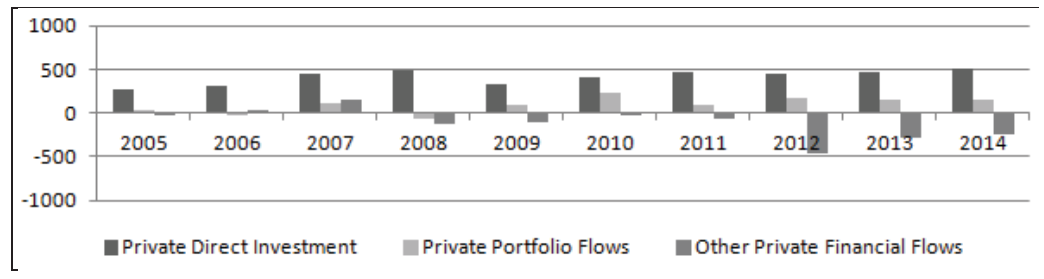

Most of the capital flow was concentrated in Asia, Latin America and Central and Eastern Europe (fig. 3). After global financial crisis, the private financial flows decreased all regions. Although the financial flows started to increase again in these regions, financial flows couldn't reach the pre-crisis level except Sub-Saharan Africa and Latin America. Especially, Asia experienced a significant decline in 2012. Latin America and Caribbean only experienced a better increase in financial flows than the others. This result shows that financial flows are not addressed yet fully.

Figure 3. Private Financial Flows by Regions

\begin{tabular}{|l|c|c|c|c|c|c|c|c|}
\hline & $\mathbf{2 0 0 5}$ & $\mathbf{2 0 0 6}$ & $\mathbf{2 0 0 7}$ & $\mathbf{2 0 0 8}$ & $\mathbf{2 0 0 9}$ & $\mathbf{2 0 1 0}$ & $\mathbf{2 0 1 1}$ & $\mathbf{2 0 1 2}$ \\
\hline Central and Eastern Europe & 103.6 & 116 & 183.8 & 157.1 & 30.9 & 83.1 & 93.9 & 66.8 \\
\hline Commonwealth of Independent States & 29.3 & 51.5 & 130.2 & -98 & -63.4 & -25.4 & -64.9 & -57.9 \\
\hline Developing Asia & 123 & 83.4 & 197.1 & 68.2 & 206.2 & 409 & 311.9 & 14.4 \\
\hline Latin America and the Caribbean & 37.8 & 34 & 85.8 & 84.9 & 61.9 & 128.9 & 200 & 136.3 \\
\hline Middle East, N. America, Afg. and Pakistan & 0.9 & 15.6 & 77.2 & 44.4 & 71.9 & 19 & -43.8 & -35.2 \\
\hline Sub-Saharan Africa & 17.7 & 8.1 & 16.8 & 22.3 & 13.5 & -14.7 & -1.7 & 20.4 \\
\hline
\end{tabular}

Source: IMF, World Economic Outlook, April 2013. 


\section{The Global Financial Crisis and Turkish Economy}

Turkish economy had felt the effect of global financial crisis as in other developing countries. However, Turkish economy is more resilient to external shocks than it was a decade ago for two reasons: (i) financial institutions in Turkey have had less exposure to the United States subprime mortgages and structured credit products than those in other parts of the world; and (ii) in Turkish economy, improvements have been made to financial regulation and to macroeconomic management since the 2001 financial crisis.

The global financial crisis has affected Turkish economy via trade channel. The decline in trade in the rest of the world led to fall the Turkish foreign trade by reducing the firms ability on production capacity. Thus, the crisis has started to influence on real sector in Turkey instead of the financial sector (Terzi, 2010, p. 254).

Turkey experienced a strong and sustained period of economic expansion after the 2001 recession, with gross domestic product growing at an average annual rate of 6.8 per cent between 2002 and 2007. However, the global financial crisis has led to a significant slowdown in economic activity in Turkey as in other developing countries. A remarkable tightening in lending conditions and a surge in interest on loans were experienced during the worst period of the financial crisis (YImaz, 2009). Declines in external demand and internal demand of Turkey have negatively affected her growth. As a result, Turkey's economy experienced a significant decline in GDP in 2009. After that, although there is an increase in GDP, it doesn't reach pre-crises level in Turkey (Fig. 4).

Figure 4. Growth Rate in Turkey, \%, 2001-2012

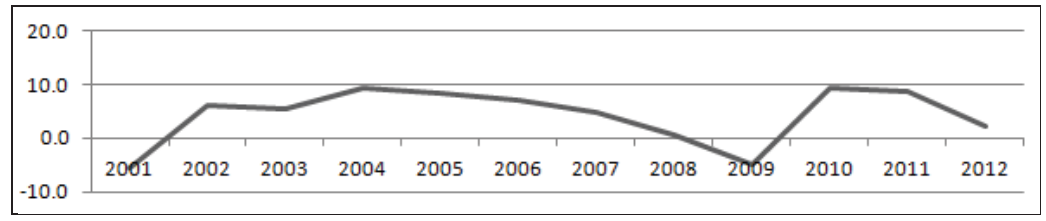

\section{Source: TURKSTAT}

Global financial crisis has also affected the balance of payment in Turkish economy. Following figure shows the current account in Turkish economy. The current account deficit has declined since November 2008 (Fig 5). This can be seen a positive situtation for Turkish economy. However, the reason of this decline is a decrease on both exports and imports. This is a feedback of global financial crisis. The decrease in trade of the rest of the world countries has led to a decline in foreign trade in Turkish economy (Terzi, 2010, p.250).

Figure 5. Current Account Deficit in Turkey, 2001-2012 (Million USD Dollar)

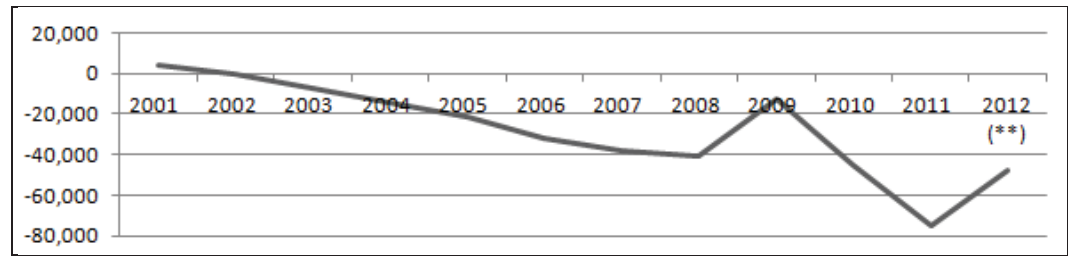

\section{Source: CBRT}

As mentioned above, Turkish economy experienced a decline in both export and import in 2009 (Fig.6). The sharp decline in the value of Turkish exports resulted from falling volumes as well as falling prices. The developments in global trade shows that (i) the volume of Turkish exports has closely followed the falling volume of world imports, but (ii) export prices of Turkey have fallen more than the global import prices (Uygur, 2010). Although measures have accommodated signals of the diminishing effect of the crisis and the start of recovery in trade in 2010, these signals still remain weak. While recent data on trade indicates that the situation is moderate, the recovery is slow. An appreciation in Turkish Liras also causes a slower recovery in export in Turkey because of the competitiveness. 
Figure 6. Foreign Trade in Turkey, 1998 -2012 (Thousand USD dollar)

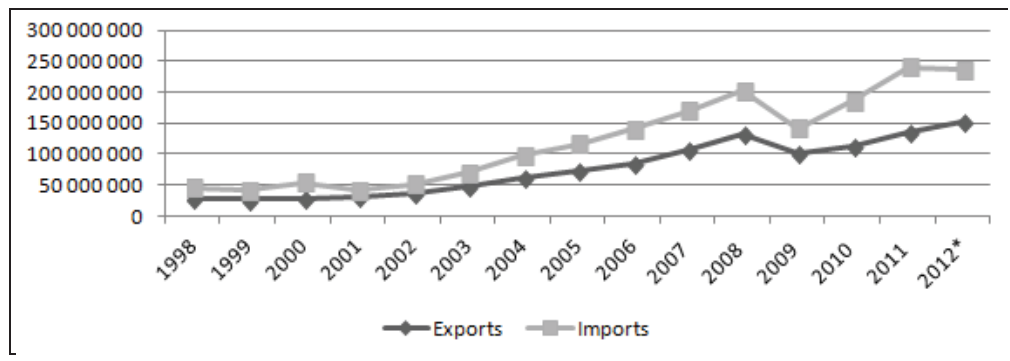

The decline in trade in the rest of the world led to fall the foreign trade and this also reduced the firms capacity on production. Industrial production index decreased in 2009 (Fig. 7). However, as a result of measures, industrial production index started to increase again in Turkish economy.

Figure 7. Industrial Production Index in Turkey, 2005-2010

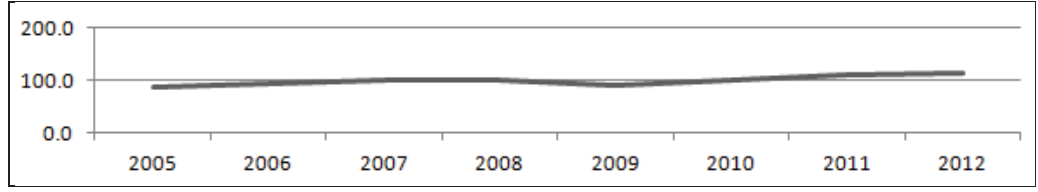

\section{Source: TURKSTAT}

The labour market felt the impact of the shock through rising unemployment. As demand fell, the unemployment rate, which averaged about 10 per cent in 2006-2007 increased to 11 per cent in 2008 and 14 per cent in 2009 (Fig.8). Some of those who lost their jobs due to the contraction in industrial output turned towards work in the agricultural sector. There are signs that the measures taken in 2008 and 2009 have helped to bring a partial recovery in the employment situation, which had deteriorated due to the global economic crisis.

Figure 8. Unemployment Rate in Turkey

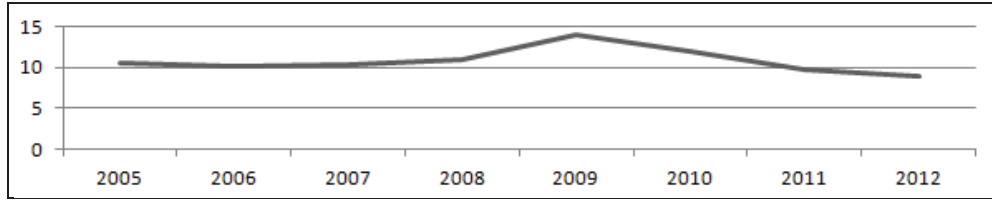

\section{Source: TURKSTAT}

\section{Capital Flows and Policy Reforms in Turkey}

The global financial crisis that has spread around the world has caused a considerable slowdown in most developed countries and has already affected financial markets and growth prospects in developing countries, including Turkish economy.

Turkey has gone through three crises since it opened up its capital account in 1989. The first instance was 1994, when a misguided attempt to keep domestic interest rates low led to a sudden capital outflow. The second was in 2001, when a minor political crisis threw the sustainability of an exchange-rate-based stabilization program into question and led to a massive withdrawal of funds. And the third happened in 2008 as a result of the global flight to safety that the US sub-prime mortgage crisis sparked (Rodrik, 2012, p.44). 
The financial crises have affected on private capital flows in Turkey, negatively. To clarify the effects on capital flows in Turkey, Turkish economy is analyzed two sperate periods: the period of 1989 and 1999 and after 2000.

\subsection{Capital Flows between 1989 and 1999 in Turkey}

During 1990-2000 period, instabilities in the global economy increased significantly. When this period is analyzed, it is seen that developed economies, other than the USA, have an instable and low growth performance. Emerging economies experienced major financial crises which had reflections on global scale. Furthermore, negative impact of the Gulf Crisis in 1991 deeply affected the economies of that region, mainly the Turkish economy. In the mentioned period, global capital flows accelerated and Turkish economy was often exposed crisis (BRSA, 2010, p.7).

After the financial liberalization, the Turkish economy's performance became heavily dependent on highly volatile short-term capital flows with costly ramifications. Given its domestic weaknesses, the Turkish economy has failed to capitalize during this period on the growing volume of foreign direct investment directed towards emerging markets. In addition, by the Gulf Crisis, Turkish economy was hit by negative external shock and the market experienced a sudden international capital reversal. Moreover, as a result of domestic weakness, Turkey encountered its first crisis in 1994. The crisis of 1994 was an important setback to the Turkish economy and also captal flows. After crisis, capital flows has continued to fluctuate (Fig.9).

Figure 9: Capital Flows in Turkey, 1989-1999, Million USD

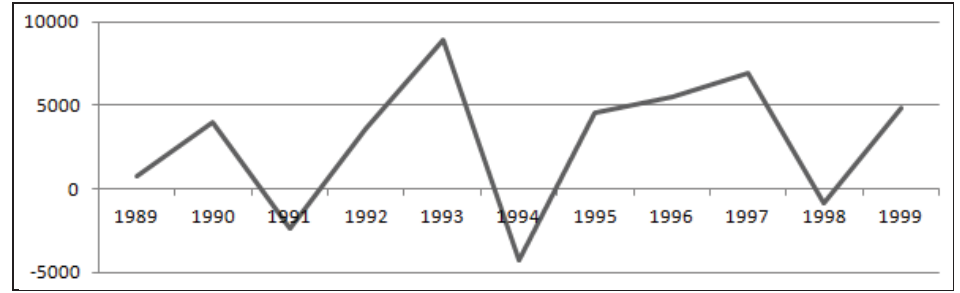

\section{Source: CBRT}

By the end of the 1990s, with fiscal deficits and high rates of inflation, there was growing awareness that the Turkish economy was on an unsustainable course. This led to the signing of a stand-by agreement with the IMF in December 1999 which involved a combination of measures aimed at fiscal adjustment and medium-term structural reforms. IMF program failed to provide sufficient protection, and the Turkish economy remained highly vulnerable given the broad extent of adjustment and the weak commitment on the part of the coalition government to some of the key components of the program such as privatization and the regulation of the banking system. Therefore, the Turkish economy experienced in November 2000 and February 2001 crisis. With the crisis, there was a reduction in capital flows (Fig. 13).

\subsection{Capital Flows and Policy Reforms after 2000 in Turkey}

November 2000 and February 2001 financial crises led to a process of restructuring of the Turkish banking sector as a result of which banks and financial institutions started to operate in a more efficient way. In 2000, Banking Regulation and Supervision Agency (BRSA) was established in order to undertake the task of auditing the sector in single hand. The aim of the Banking Regulation and Supervision Agency is to regulate the principles and procedures of ensuring confidence and stability in financial markets, the efficient functioning of the credit system and the protection of the rights and interests of depositors (BRSA, 2007)

Reforms implemented after the financial crises experienced and the political stability obtained after 2002 have provided a significant improvement in fundamental indicators. As a matter of fact, with also the effect of global developments, within the period of 2002-2005 distinctly from previous periods a stable improvement was experienced in macroeconomic framework. Alongside with the high growth performance in the 2002-2005 period, the inflation was decreased to single digit levels, the short-termed policy interest rates were decreased below $20 \%$ and the share of public debt within national income was also decreased. The improvement of Turkish economy and the increase of the interest of global capital have caused a strong capital entry oriented directly to country and formed as portfolio investment and 
foreign direft investment (BRSA, 2010, p.8).

To ease the negative effects of the global crisis on Turkey, a series of measures were adopted by the authorities and organizations. Within this framework the Central Bank took many measures. The Banking Regulation and Supervision Agency, on the other hand, adopted certain measures aimed at preserving the financial strength of banks and containing the effects of abrupt changes in the financial asset prices on banks' capital adequacies. The Government also announced some measures in order to ease the effects of the global financial crisis. Additional measures were continued to be implemented also by various organizations in the first months of 2009 as the global volatility continued to affect the markets. These measures included liquidity supports, tax and premium incitements, credit and guarantee incitements through production and exports, financing supports. These measures are summarized following figure 11.

Figure 11. Measures taken by authorities in Turkey

\begin{tabular}{|c|c|}
\hline Central Bank & $\begin{array}{l}\text { - resumed its activities as an intermediary in the foreign exchange deposit market until the removal } \\
\text { of uncertainties in international markets; } \\
\text { - raised its transaction limits by twofold to USD } 10.8 \text { billion and extended the lending maturity to } 1 \\
\text { month from } 1 \text { week in the foreign exchange deposit market; } \\
\text { - adopted a strategy to use foreign exchange reserves to primarily support the foreign exchange } \\
\text { liquidity need of the banking system. The reserve requirement ratio was unchanged at } 6 \text { percent in } \\
\text { TL liabilities, but it was lowered to } 9 \text { percent from } 11 \text { percent in foreign exchange liabilities. } \\
\text { - increased the exports rediscount credit limit by USD } 500 \text { million to USD } 1 \text { billion in order to contain } \\
\text { the effects of the global crisis on industry sectors. Additionally, the rules and principles applicable to } \\
\text { the exports rediscount loan limit were rearranged for rendering the use of these loans easier. } \\
\text { - The Central Bank cut its interest rates and extended the maturity in foreign exchange deposit } \\
\text { market in order to prevent a possible foreign exchange squeeze in the financial market. }\end{array}$ \\
\hline Government & $\begin{array}{l}\text { - consumption tax applied to durable goods and automobiles to be lowered for a period of } 3 \text { months, } \\
\text { - value added tax applied to real estates to be lowered to } 8 \text { percent from } 18 \text { percent for a period of } 3 \\
\text { months, } \\
\text { - an additional subsidy of TL } 75 \text { million to be extended to SMEs, } \\
\text { - resource utilization support fund to be cut by } 5 \text { percentage points, } \\
\text { - capital of Eximbank to be increased, } \\
\text { - discounted night tariff for pricing the use off electricity in industry sector that applied to weekdays } \\
\text { only to be extended to cover also weekends and other public holidays. } \\
\text { - the Government sought authorization from the Parliament for increasing and determining for a } \\
\text { period of two years the deposit insurance coverage, which was TL } 50,000 \text {. } \\
\text { - introduced a new package of measures including implementations in the crisis environment for } \\
\text { companies, employees and the retired people; the term for the "short term employment } \\
\text { compensation" implemented over Unemployment Fund was extended to } 6 \text { months from } 3 \text { months, } \\
\text { and the sum of compensation was raised by } 50 \text { percent. It was adopted that no seizure could be } \\
\text { levied on retirement wages, and effective term of the incentives for } 49 \text { provinces was extended by } 1 \\
\text { more year. }\end{array}$ \\
\hline BRSA & $\begin{array}{l}\text { - required banks to get permission for distribution of the } 2008 \text { earnings; } \\
\text { - allowed banks to reclassify the securities in their balance sheet from trading portfolio to investment } \\
\text { portfolio for once only; } \\
\text { - allowed banks to restructure the loans apparently posing no problems in order to ensure smooth } \\
\text { functioning of the loan relations between banks and non-financial institutions. }\end{array}$ \\
\hline $\begin{array}{l}\text { Other } \\
\text { measures }\end{array}$ & $\begin{array}{l}\text { the Finance Ministry introduced tax advantages for sectors. Accordingly, payment of the tax dues } \\
\text { which became payable before } 1 \text { September } 2008 \text { was decided to be deferred to December } 2008 \\
\text { and with } 18 \text { installments. Within the framework of other measures package announced on } 25 \text { March } \\
2009 \text { the Government reduced the rate of Vat received from the sale of offices and other workplaces } \\
\text { to } 8 \text { percent, the public fee in real estate purchases to } 0.5 \text { percent from } 1.5 \text { percent, the rate of Vat } \\
\text { imposed on furniture, certain industrial and work machines used particularly by SMEs, information } \\
\text { technology products and office furniture to } 8 \text { percent from } 18 \text { percent to be effective for a period of } \\
\text { three months. }\end{array}$ \\
\hline
\end{tabular}

Source: BAT, The Banks Association of Turkey, "The Financial System and Turkey", October 2009, Istanbul.

Measures were also taken on capital flows in Turkey. Measures taken by authorities to promote capital flows are as follow: 
Figure 12. Measures on Capital Flows in Turkey

\begin{tabular}{|l}
$\checkmark \checkmark$ in November 2008, the parliament adopted an "Asset Peace Law" under which there would be a tax amnesty \\
for all unrecorded assets, including cash, securities, other capital market instruments and real estate, if they \\
are declared. No tax inspections or reassesments would be made on the declared assets. Only a 2\% tax would \\
be imposed on assets of foreign origin if they are repatriated or declared for repatriation. The tax rate would be \\
$5 \%$ for domestic assets declared. The law was applicable till March 2009, but was extended again till 30 \\
\\
September 2009. \\
$\checkmark$ The witholding tax on credits obtained from foreign creditors was reduced to 5\% from 15\% in March 2009. \\
$\checkmark$ Foreign fund managament companies that are not subjected to corporate taxation would need to pay income \\
tax only for those incomes they earned through their portfolio management companies set up in Turkey. \\
$\checkmark$ Incomes generated from (i) sake of shares of legal entities established outside of Turkey, (ii) dividens of legal \\
entities established outside Turkey, and (iii) commercial activities conducted abroad, would be exempt from \\
taxation provided that these incomes were transferred to Turkey by 31 May 2009.
\end{tabular}

Source: Uygur, Ercan.(2010), The Global Crisis and Turkish Economy, TWN Global Economy Series, Malasia.

Generally, above measures on capital flows focused on tax amnesty and tax exempt for foreign companies and foreign creditors. As seen from the figure 13, with the measures on capital flows, declining capital flows in global financial crisis have tended to increase again (fig.13). The confidence of foreign investor to Turkish economy has increased and continued their investment. Surely, recovery on capital flows can not directly connect to the improvements in tax. The development of capital flows should be thought by other measures in financial market.

Figure 13. Capital Flows in Turkey, 2000-2012, million USD dollars

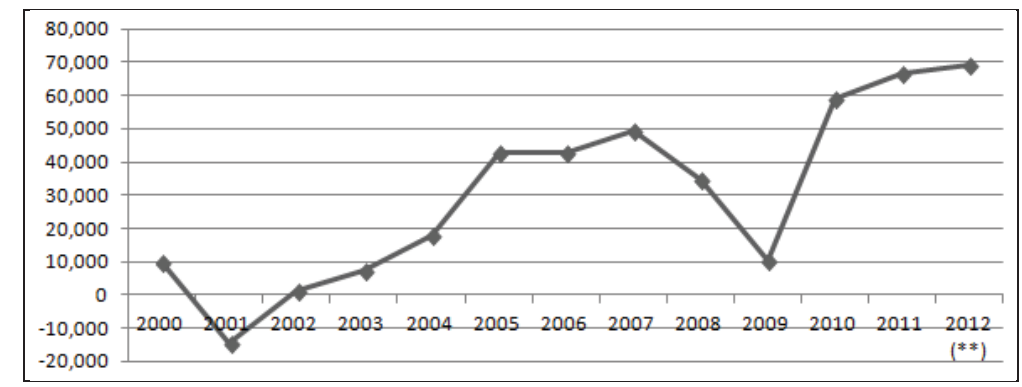

\section{Source: CBRT}

\section{Conclusion}

In this paper, I will try to analyze the capital flows and policy reforms in Turkish economy after crisis. Global financial crisis has affected both developed and developing countries. The crisis also influenced the direction of the capital flows. With the global financial crisis, capital flows tend to flight from developing countries like Turkey. In Turkey, capital flows generally have followed a fluctuating condition since liberalization of capital account and it has decreased with the crises. Capital flows in Turkey decreased after the global financial crisis as they did before. However, it has continued to increase as a result of moderate measures. Measures implemented since 2001 has affected financial stability, positively. Therefore, the decrease in capital flows didn't spread to very a long period and capital inflows has continued to proceed beyond pre-crisis level.

\section{References}

BRSA (2007), Banking Regulation and Supervision Agency, Financial Markets Reports.

BRSA (2010), Banking Regulation and Supervision Agency, From Crisis to Financial Stability: Turkey Experience, Working Paper.

Cali, M, I. Massa and D. W.te Velde, (2008) "The Global Financial Crisis: financial flows to developing countries set to fall by one quarter", ODI, November 2008, pp.1-25. 
CBRT, Central Bank of Republic of Turkey www.tcmb.gov.tr

IMF, World Economic Outlook, April 2013.

Kmainsky, G,(2005) "International Capital Flows, Financial Stability and Growth", DESA Working Paper No.10 December, pp.1-24.

Lopez-Mejia, A. (1999). "Large Capital Flows Causes, Consequences and Policy Responses" Finance \& Development 36(3).

Rodrik, D. (2012) "The Turkish Economy after Global Financial Crisis" Ekonomi-tek Volume 1 January, pp.41-61.

Uygur, Ercan. (2010), The Global Crisis and Turkish Economy, TWN Global Economy Series, Malasia.

Terzi, N. (2010) "Global Financial Crisis and the Effects of its on Turkish Economy" 6th. International Scienific Conference, Business and Management, May 13-14, 2010, Vilnius Lithuania.

TURKSTAT, Turkish Statistical Institute, www.turkstat.gov.tr

Uygur, E.(2010) The Global Financial Crisis and Turkish Economy,TWN Global Economy Series, 21.

World Bank, (1995). "Managing Capital Flows in East Asia".

Yılmaz, D. (2009) "Turkey's economy and Financial Crisis", at The Society for Economic Dynamics Annual Meeting, Istanbul, BIS Review, 134, 1 July. 